\title{
'Behaviour and Morality have
}

\section{Remained Irreproachable, and his}

Commercial Reputation is Good'

\author{
Applying for Naturalisation in Late-Nineteenth-Century Antwerp \\ and Rotterdam
}

CHRISTINA REIMANN

In the late nineteenth century, with the expansion of their harbours and the growth of transatlantic mobility, the port cities of Antwerp and Rotterdam became home to economically important and large migrant communities. In a context marked by the often-claimed rise of the nation state, when national legislation concerning nationality and citizenship was shifting, local authorities and citizens played an important but still underestimated role when it came to enforcing the naturalisation of foreign nationals. Applications for naturalisation in both Antwerp and Rotterdam were firmly rooted in the local context, and economic performance was key to the police commissar's support of an applicant's case towards the national authorities. By comparatively analysing individual applications for naturalisation in Antwerp and Rotterdam, this paper argues that the close relationship between the nation-state and the mechanisms of legal inclusion and exclusion on which it rested, has to be relativised.

Aan het eind van de negentiende eeuw werden de steden Antwerpen en Rotterdam, dankzij de uitbreiding van hun havens en de groei van de transAtlantische mobiliteit, de thuisbasis van grote en economisch belangrijke migrantengemeenschappen. In een periode die in de historiografie vaak gekenmerkt wordt door de veronderstelde opkomst van de natiestaat en veranderende 
wetgeving omtrent nationaliteit en burgerschap, speelden lokale overheden en burgers een belangrijke, maar nog vaak onderschatte rol bij het bewerkstelligen van naturalisatie van mensen met een migratieachtergrond. Zowel in Antwerpen als in Rotterdam waren naturalisatieverzoeken duidelijk gesitueerd in de lokale context van de aanvrager. Zo was het economische succes van een aanvrager een doorslaggevende factor voor het verkrijgen van steun van de politiecommissaris. Deze steun vergrootte de kans van slagen van een naturalisatieaanvraag bij de nationale overheid. Aan de hand van een vergelijkend onderzoek naar individuele naturalisatieaanvragen in Antwerpen en Rotterdam, stelt dit artikel dat de hechte relatie tussen de natiestaat en de mechanismen van wettelijke in- en uitsluiting waarop die berust, moet worden gerelativeerd.

Nationality and citizenship are among the legal institutions that are usually seen to be most closely tied to the modern nation state. ${ }^{1}$ Yet, as this article will argue, these terms also connote administrative and legal practices that even at the heyday of the nation state in the late nineteenth century, have played out in municipalities. This holds particularly true for Western European port city municipalities as these, in particular during the age of steam (c. 1870-1940), were nodes of migration and home to many foreign-born residents with transnational life paths and mobile lifestyles. With the communication and transportation revolutions in the last third of the nineteenth century, the port cities of Antwerp and Rotterdam were responsible for more than controlling immigration and emigration to and from Europe, the colonies, and the American continent. ${ }^{2}$ These port cities, with their fluid populations, turned into sites where nation states could negotiate the boundaries of national belonging for newcomers and longtime foreign residents.

However, historical research has not yet addressed this local rootedness and the actual practice of how citizenship and nationality of mobile people were handled in port cities. ${ }^{3}$ This article sets out to uncover the role of city authorities and local populations in Antwerp and Rotterdam in 'making' new nationals or citizens, especially through naturalisation. It will propose the argument that port cities' authorities did not follow a

\section{Ausschließen: Die Nationalisierung der}

Staatsangehörigkeit vom Deutschen Bund bis zur Bundesrepublik Deutschland (Göttingen 2001); Patrick Weil, Qu'est-ce qu'un Français? Histoire de la nationalité française depuis la Révolution (Paris 2005).

2 Christina Reimann, 'People on Lists in Port Cities: Administrative Migration Control in Antwerp and
Rotterdam (c. 1880-1914)', Journal of Migration History 6:2 (2020) 182-208. DoI: https://doi. org/10.1163/23519924-00602002.

3 Andreas Fahrmeir and Stuart Jones open the debate on local definitions of citizenship by looking at local variations of the exercise of political and social rights in their article 'Space and belonging in modern Europe: citizenship(s) in localities, regions, and states', 
national agenda when formulating their recommendations in whether a candidate should or should not be granted naturalisation, to the national administrators. Not the concept of nationality as a symbolic and abstract relationship between the individual and the nation state, but rather local interests motivated authorities in port cities when presenting an application to the national decision-makers. At the same time, the parallel investigation of Antwerp and Rotterdam will show too, that national legislation determined the way in which local authorities tailored naturalisation procedures to their own, mostly economic, interests.

With its focus on the local dimension of naturalisation, this article follows recent advances in migration history suggesting that local authorities held an important share in the regulation of migration well into the twentieth century. ${ }^{4}$ This article maintains that local authorities also had a say in naturalisation procedures, a role that has yet to be acknowledged by historical research. This article further follows the now established approach to migration policy by examining (local) administrative practice rather than the legislation process. ${ }^{5}$ As will be shown, when dealing with the applications for naturalisation by mobile people, port city authorities tried to accommodate both their specific port city's interests and the national legal framework.

This article does not aim to give a representative picture of all local naturalisation procedures in Antwerp and Rotterdam. Rather, it analyses several applications between 1870 and 1900 from port city residents with mobile life paths who belonged to the cities' major migrant communities in their double context: the local port city and the national legal context. Migrant communities that conducted business in the ports became increasingly important for the port city economy in both Antwerp and Rotterdam during the late nineteenth century. This was true especially for migrants from neighbouring countries, Germany in particular. The legal context regarding the granting of nationality and citizenship to foreign

European Review of History: Revue européenne d'histoire 15:3 (2008) 243-253, DOI: https://doi. org/10.1080/13507480802082565. They only briefly consider naturalisations.

Policies and Materialities of Identification in European Cities. Papers and Gates, 15001930 (New York 2018). DOI: https://doi. org/10.4324/9780429435065. For the Antwerp case in particular see Ellen Debackere, Welkom in Antwerpen? Het Antwerpse vreemdelingenbeleid, 1830-1880 (Leuven 2020).
5 Anne-Sophie Bruno et al., 'Jugés sur pièces: Le traitement des dossiers de séjour et de travail des étrangers en France (1917-1984), Population 61:5/6 (2006) 737-762. DoI: https://doi.org/10.3917/ popu.605.0737; Christiane Reinecke, Grenzen der Freizügigkeit: Migrationskontrolle in Großbitannien und Deutschland, 1880-1930. Veröffentlichungen des Deutschen Historischen Instituts London/ Publications of the German Historical Institute London 68 (Munich 2010). DOI: https://doi. org/10.1524/9783486707601. 


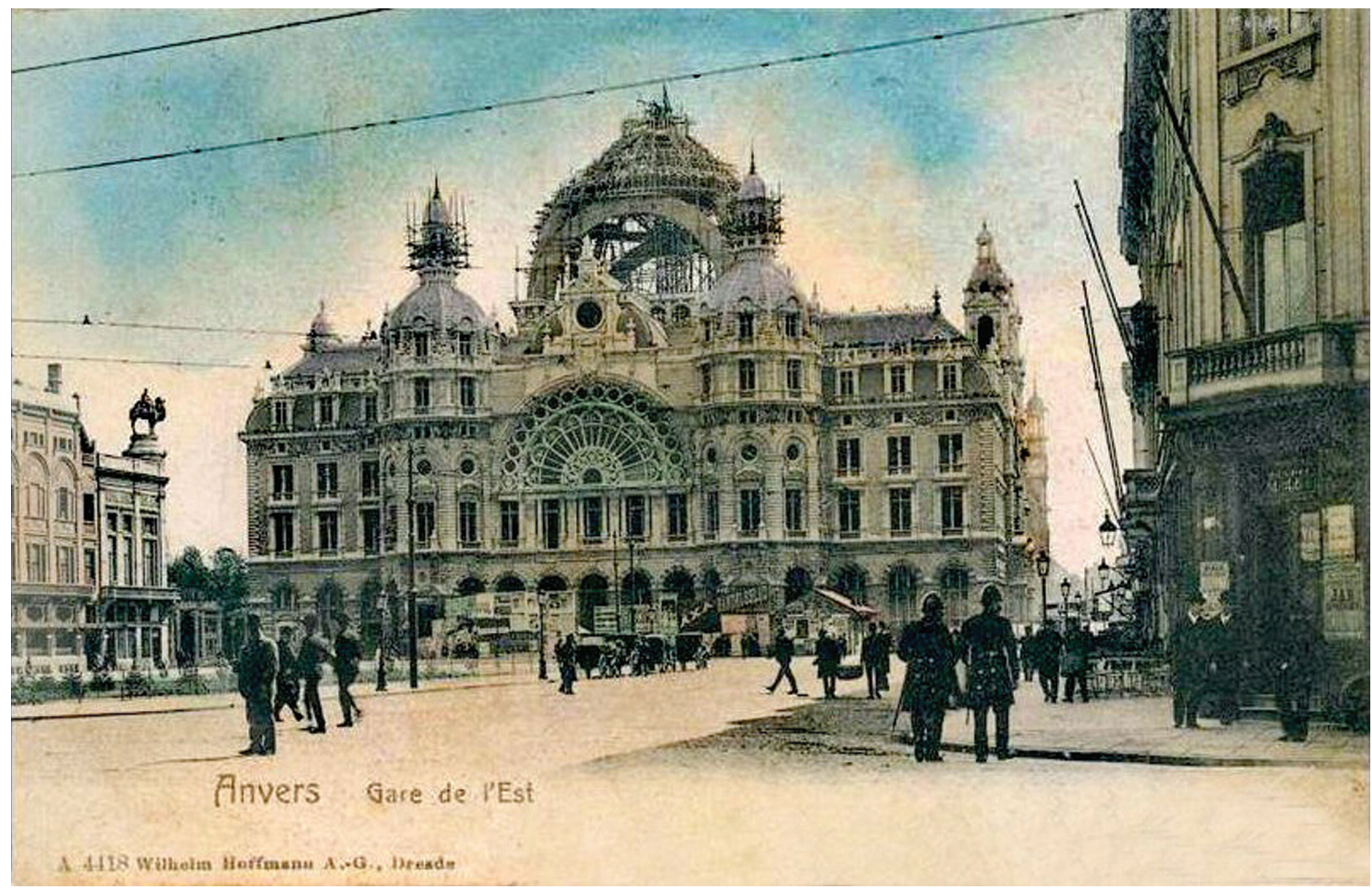

$\Delta$

Antwerp Central Station under construction at the very beginning of the 1900 . The Central Station became the symbol of the modernising port city and the transportation revolution with its increasing traffic on both railways and the sea. Postcard produced by Wilhelm Hoffmann A.-G. Dresde. The picture belongs to the public domain and is available via Wikimedia Commons: https://commons.wikimedia.org/wiki/File:AnversGaredeEst-Construction-1900.jpg. 
residents from the 1880 on onwards developed in opposite directions in the Netherlands and Belgium: the Belgian parliament voted on laws to open up the Belgian nationality, whereas Dutch legislation made accession to nationality and citizenship more exclusive. ${ }^{6}$

By pointing to the dynamic relationship between national legislation and local administrative practice, this analysis complicates the usual explanation that the development of the nation state brought about the transformation of legal institutions like nationality and citizenship. ${ }^{7}$ This article tells a local history of national belonging by emphasising the role that local authorities played in re-defining the boundary between nationals and foreigners in the late nineteenth century. To be sure, the final decision about whether an application for naturalisation was successful was made solely by the national parliaments. This article does not study these 'final results' or to what extent the local authorities could actually influence parliamentary decisions. It is nearly impossible to speculate on this, since the parliaments did not have to account for their decision-making. Rather, this article considers the applications for naturalisation made by 'typical' foreign-born, mobile, port city residents within their local context, by acknowledging that local practices were embedded in a national legal framework.

At the turn of the nineteenth century, a period in Western Europe marked by democratisation and the increasing involvement of the nation state in social matters, the possession of national citizenship took on a new significance for both individuals and the state. Nationality and citizenship entailed more rights, such as basic social rights and the right to vote, and obligations, in other words military duties. These rights and obligations gave meaning to the otherwise abstract legal bond between the individual and the van nationaliteitsverwerving, -toekenning en -verlies in België, 1830-1909', Belgisch Tijdschrift voor Nieuwste Geschiedenis XXVII:3-4 (1997) 323349; 'Vluchtelingen en de transformatie van nationality for foreign-born people: Eric Heijs, Van vreemdeling tot Nederlander: De verlening van het vreemdelingenbeleid in België (1860-1914)', Belgisch Tijdschrift voor Nieuwste Geschiedenis 40:3 het Nederlandschap aan vreemdelingen 1813-1992 (Amsterdam 1995). For the Belgian case, the work by Frank Caestecker extensively covers the question from a legal historical perspective. See in particular 'La législation belge relative à la nationalité 1830-1984', in: Frank Caestecker et al., Devenir belge: Histoire de l'acquisition de la (2010) 345-381.

7 See for example Gosewinkel, Einbürgern und Ausschließen; Gérard Noiriel, La tyrannie du National: Le droit d'asile en Europe, 1793-1993 (Paris 1991); Frank Caestecker, Alien Policy in Belgium, 1840-1940: The Creation of Guest Workers, Refugees and Illegal Aliens (New York 2000). 


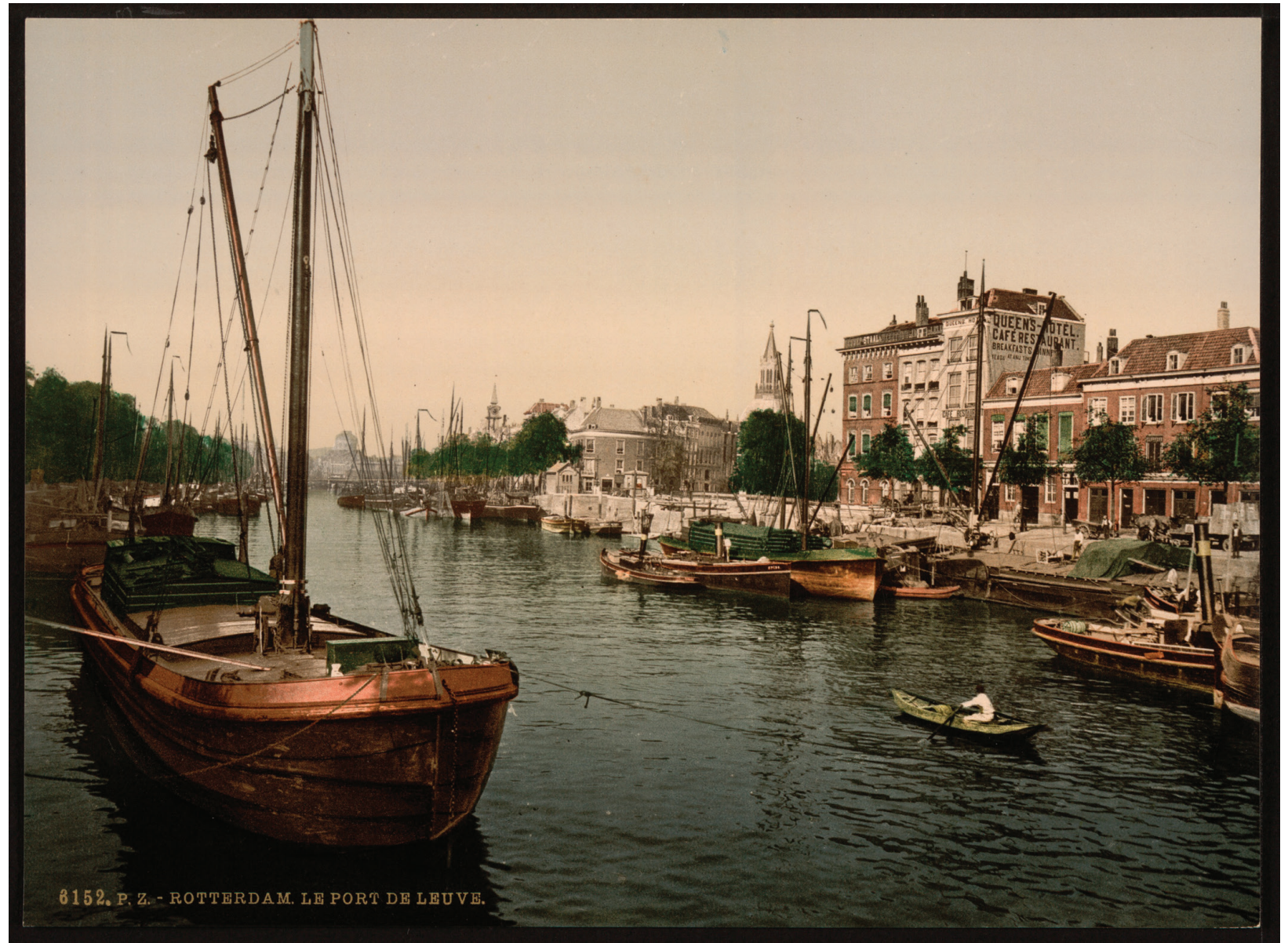

$\Delta$

'The Port of Leuve' in Rotterdam. This photograph is held by the us Library of Congress and was produced between 1890 and 1900 by an unknown author. In the nineteenth century, the Port of Leuve was Rotterdam's central harbour where the port activity involving many foreign nationals was taking place. There are no known copyright restrictions on reproduction. The picture is available via Wikimedia Commons: https://commons.wikimedia.org/wiki/File:The_ Port_of_Leuve,_Rotterdam,_Holland_LOC_4120064578.jpg. 
state. The reform of legal norms between the 188 os and the early 1900 that defined nationality and citizenship also transformed the dynamic dimensions of these concepts, namely the naturalisation procedure, the granting of the denizen status, and the option for nationality by foreign-born residents.

Still, the shift in the content and significance of nationality and citizenship was far from uniform in Western Europe. This becomes clear in Belgium and the Netherlands, two neighbouring countries with a common past, but with important differences in political culture, economic development, and social structure. The frequently-drawn picture of a general 'nationalisation' of Western European societies indeed masks the nuances and lived experiences of possessing or receiving nationality, which, despite the increasing importance of the nation state, were bound to people's local living worlds. This was particularly the case in the reshaping of legal terms of nationality when port cities worldwide became hubs of international mobility. International business and labour migration, transmigration, and inner-state migration increasingly affected port cities, transforming them into places of arrival, passage, and departure ${ }^{8}$, and into places that dealt with national belonging in a specific way.

This article will proceed in four steps. It begins by outlining the contrasting development of the Belgian and Dutch legislation concerning accessibility to nationality and citizenship. Following this, it provides an overview of the national naturalisation procedures. In its third and fourth parts, it analyses the local management of applications made by foreign-born residents with transnational life paths. The applicants belonged to the largest and economically most important migrant communities in Antwerp and Rotterdam, which were largely composed of highly-mobile businesspeople from neighbouring countries. German-born residents in particular, often were part of the socio-economic elite in these port cities: during the late nineteenth century, German merchants played an important role in the ports' transit economies and owned a number of international trading firms. ${ }^{9}$

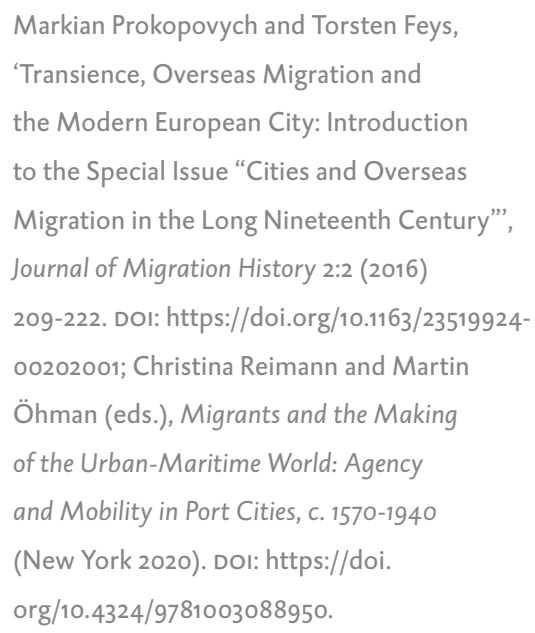

9 Paul van de Laar, 'Bremen, Liverpool, Marseille and Rotterdam: Port Cities, Migration and the Transformation of Urban Space in the Long Nineteenth Century', Journal of Migration History 2:2 (2016) 275-306. DoI: https://doi. org/10.1163/23519924-00202004; Hilde Greefs, 'Exploiting International Webs of Relations: Immigrants and the Reopening of the Harbour of Antwerp on the Eve of the Nineteenth Century', in: Adrian Jarvis and Robert Lee (eds.), Trade, Migration and Urban Networks in Port Cities, c. 1640-1940 (St. Johns 2008) 81-109. DOI: https://doi. org/10.5949/liverpool/9780973893489.003.0006. 


\section{Nationality and Citizenship Law in Nineteenth-Century Netherlands and Belgium}

According to the Civil and Alien Laws of both countries, foreign-born residents of Antwerp and Rotterdam could have a number of different overlapping statuses of belonging: foreign nationals without any formal link to their actual place of residency; foreign nationals with an official residency permit; foreign nationals possessing civil equality with nationals (denizen status); naturalised Belgian or Dutch allowed to hold public offices; naturalised citizens who thanks to their gender and property received active and passive voting rights together with naturalisation ${ }^{9}$; and colonial subjects who were denied the status of nationals, let alone citizens. ${ }^{10}$ What these different statuses entailed in terms of individual rights and obligations became subject to change with suffrage reforms and the establishment of public social security systems in particular.

In the late nineteenth century, however, nationality and citizenship were not equivalent concepts or forms of social status. This is for example underlined by the fact that women possessing nationality were not citizens of their country. In the Netherlands and Belgium, citizenship remained inaccessible to all female nationals up until 1919 and 1948 respectively. As long as suffrage remained linked to property, citizenship did not automatically come with being male either. Yet, nationality as the legal bounds of the national community was, and still is, a pre-condition for citizenship. Nationality denotes the 'relationship between an individual and a nation involving the duty of obedience or allegiance on the part of the subject and protection on the part of the state'. ${ }^{11}$ Citizenship is the basis for the individual's right to political participation. ${ }^{12}$

In Belgium, the process of defining national belonging was accompanied by legal reforms designed to broaden the national community, by making Belgian nationality and citizenship more accessible to foreignborn residents. In the Netherlands, the increasing importance of nationality and citizenship was accompanied by a closer legal demarcation between the national community and foreign residents who aspired to Dutch nationality and citizenship. While building their empires, both the Netherlands and

Belgian territory and could only come to

Belgium under exceptional circumstances. Guy

Vanthemsche, Belgium and the Congo, 1885-

1980 (Cambridge 2012) 63. DOI: https://doi.

org/10.1017/Сво9781139043038.

11

Corpus luris Secundum 65 (New York 1966) 52,

quoted in: Dieter Gosewinkel, 'Citizenship,

Subjecthood, Nationality: Concepts of Belonging in the Age of Modern Nation States', in: Klaus

Eder and Bernhard Giesen (eds.), European

Citizenship: Between National Legacies and

Postnational Projects (New York 2001) 17-35, 25.

12 Staatsbürgerschaft in Europa im 20. und 21. Jahrhundert (Berlin 2016) 18-19. Gosewinkel's approach stands out by reflecting upon different national traditions. 
Belgium excluded colonial populations from the legal nation by denying them all formal means of belonging as well as the right to vote.

Since 1831, when Belgium gained its independence from the United Kingdom of the Netherlands, both countries' nationality and citizenship were regulated by the Civil Code (Burgerlijk Wetboek or Code Civil) which stemmed from the Napoleonic Civil Code of 1804. The Dutch Burgerlijk Wetboek from 1838 established a jus soli regulation: every child born in the Netherlands or in its colonies by parents who resided in the country, regardless of whether or not they were Dutch, would automatically receive Dutch nationality. A Dutchman's wife automatically received Dutch nationality, including cases in which the husband had become Dutch via naturalisation. Throughout the nineteenth century, in both the Netherlands and Belgium, a woman's nationality was linked to her husband's national belonging. The Dutch nationality law from 1892, the Wet op het Nederlanderschap, explicitly excluded married women from individual naturalisation, and it was only in 1896 that an independent woman, a widow, for the first time received naturalisation. ${ }^{13}$ In Article Eight, the Burgerlijk Wetboek also stipulated that foreign-born residents could achieve legal equality with Dutch nationals on the level of civil rights, without possessing Dutch nationality. Such a request could be made after six years of residency on Dutch territory. ${ }^{14}$ Until the denizen status was abolished in 1892, foreign-born city dwellers in Rotterdam chose to apply for denizen status rather than naturalisation, which was a much more complicated procedure. ${ }^{15}$

To apply for Dutch nationality via naturalisation, a person had to be twenty years old, be a resident of the Netherlands or its colonies for at least ten years, and had to declare that he or she intended to remain living there. The price for naturalisation, as declared in the 1850 law, was raised to 75 guilders in $1882 .{ }^{16}$ With the 1892 law on Dutch nationality, the costs for registration and the required seal were raised as well. ${ }^{17}$ The 1892 nationality law represented an important shift. It redefined Dutch nationality and citizenship by dropping the jus soli principle in favour of a jus sanguinis regulation: from now on, only children with parents who held Dutch nationality before she was no longer married. All independent women theoretically could be naturalised, but very few actually were. N. M. Brandt, Mieke van Leeuwen-Canneman and V. van den Bergh (eds.), Naturalisatiegids: gids voor het archiefonderzoek naar naturalisaties in het Algemeen Rijksarchief (The Hague 2000). Corrie van Eijl and Marlou Schrover, 'Inleiding', in: Marlou Schrover (ed.), Broncommentaren 5: Bronnen betreffende de registratie van vreemdelingen in Nederland in de negentiende en twintigste eeuw (The Hague 2002) 7-33, 12.

15 For more details concerning the procedures of naturalisation in the Netherlands, see Brandt, Van Leeuwen-Canneman and Van den Bergh, Naturalisatiegids.

16 That year, a hundred grams of bread cost approximately 2.5 gulden, see Centraal Bureau voor de Statistiek, Tweehonderd jaar statistiek in tijdreeksen 1800-1999 (Voorburg/Heerlen 2001).

17 Heijs, Van vreemdeling tot Nederlander, 40. 


\section{S T A A T S B L A D}

VAN HET

\section{KONINKRIJK DER NEDERLANDEN.}

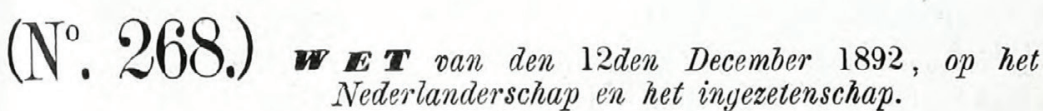

In naAm van Hare Majesteit Wilhel MiNa, biJ DB Gratie Gods, Koningin der Nederlanden, Prinses van Oranje-Nassau, enz., ENZ., ENZ.

Wij EMMa, Koningin-Weduwe, Regentes van het Koninkrijk,

Allen, die deze zullen zien of hooren lezen, saluut! doen te weten:

A]zoo Wij in overweging genomen hebben, dat het wenschelijk is, ter vervanging van den titel van het Burgerlijk Wetboek: `Van Nederlanders en vreemdelingen", en van de wet van 28 Juli 1850 (Staatsblad $n^{\circ}$. 44), gewijzigd bij die van 3 Mei 1851 (Staatsblad $n^{\circ} .46$ ), algemeene bepalingen omtrent het Nederlanderscháp vast te stellen, en dat ter voldoening aan art. 6 der Grondwet de wet mede moet verklaren wie ingezetenen zijn en eveneens bij de wet de gevolgen der naturalisatie ten aanzien van de echtgenoot en minderjarige kinderen van den genaturaliseerde behooren te worden. geregeld;

$Z_{0 o}$ is het, dat Wij, den Raad van State gehoord en met gemeen overleg der Staten-Generaal, hebben goedgevonden en verstaan, gelijk Wij goedvinden en verstaan bij deze :

\section{Artikel 1.}

Nederlanders door geboorte zijn:

a. het wettig, gewettigd of door den vader erkend natuurlijk kind, waarvan tijdens de geboorte de vader den staat van Nederlander bezit;

b. het wettig kind van een Nederlander die binnen driehonderd dagen vóor de geboorte van het kind overleed;

c. het alléén door de moeder erkend natuurlijk kind, waarvan tijdens de geboorte de moeder den staat van Nederlander bezit;

d. het noch door den vader noch door de moeder erkend natuurlijk kind, in het Rijk geboren. 
1893 would be considered Dutch from birth. The population of the Dutch Indies was legally excluded from the Dutch nation because colonised people were defined as Dutch subjects, not as nationals, let alone citizens. ${ }^{18}$ The 1892 nationality law had implications in particular for Rotterdam, as this was a location where many newcomers arrived. With the 1892 law, legislators came to consider double nationality as a social problem, in as much that foreign nationals who aspired to become a Dutch national were now forced to give up their original nationality. ${ }^{19}$ The possibility of long-term residents becoming legally equal to Dutch nationals was abolished. ${ }^{20}$

In Belgium, naturalisation developed into a more open and popular legal institution from the 188 os onwards; Belgian authorities began to encourage foreign-born residents to integrate with the Belgian legal nation. ${ }^{21}$ Before 1881 , naturalisation was regulated by the Civil Code, which stipulated that Belgian nationality followed the jus sanguinis principles. But, in administrative practice, people born to foreign parents on Belgian soil were seldom expelled and were instead considered to be lawful residents of the country. ${ }^{22}$ Like in the Netherlands, foreign-born residents could also hold equal civil rights as Belgian nationals, the so-called domicilié status. This status entitled aliens to municipal welfare and protected them from expulsion. In the early years of the Belgian state, becoming a domicilié was an exceptional favour granted to very few foreign-born residents, most of them members of the bourgeoisie. ${ }^{23}$ Unlike in Rotterdam, where numerous foreign-born residents applied for the denizen status up until 1892, applications for civil equality seem to have been a rare phenomenon in late-nineteenth-century Antwerp that left hardly any trace in the city archives. Supposedly, the applications for denizen status were taken over by the naturalisation procedure that became more popular after 1881 .

The Belgian Civil Code provided for an ordinary and a grand naturalisation. The latter not only conferred on its male holder Belgian nationality, but citizenship rights as well. The applicant for ordinary naturalisation had to be twenty-one years old and was required to have resided in Belgium for at least five years. The Naturalisation Law of 1881, followed up by the Nationality Law of 1909, introduced a shift in attitude and practice, reflecting the political elite's intention to integrate foreign-born residents into the Belgian legal nation. ${ }^{24}$ The law eased the requirements for those foreign nationals interested in applying for grand naturalisation and halved the price for ordinary naturalisations. The law particularly encouraged foreign nationals born in Belgium to opt for Belgian nationality, and contrary to the Netherlands, dual nationality was widely accepted. ${ }^{25}$

Heijs, Van vreemdeling tot Nederlander, 71.

Heijs, Van vreemdeling tot Nederlander, 74.

Van Eijl and Schrover, 'Inleiding', 11.

Caestecker, Alien Policy in Belgium, 47.

Caestecker, 'In het kielzog van de Natie-Staat', 330.

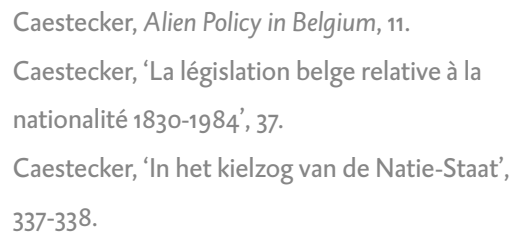

Caestecker, 'In het kielzog van de Natie-Staat', $337-338$. 
The liberalisation of nationality legislation and the will to assimilate settled immigrants went along with a strict division between Belgian nationals and foreigners, who in the late nineteenth century had begun to face increasing discrimination. ${ }^{26}$ The same was true for colonised people whose status resembled that of subjects under the Ancien Régime. Among the Congolese subjects, a differentiation was made between those who, on a 'meritocratic' basis, were registered in the population records, the so-called évolués, and those who were not officially registered. ${ }^{27}$ Only certain privileged members of the Congolese elite were theoretically allowed to ask for legal equality with Belgian nationals in some areas of civil and penal law, though the granting of these rights was rare. ${ }^{28}$

\section{Naturalisation in Late-Nineteenth-Century Belgium and the Netherlands}

In late-nineteenth-century Belgium and the Netherlands, where the importance of the category 'nationality' had begun to increase, very few foreign nationals were applying for naturalisation and even fewer would finally receive the nationality of their new country of residence. ${ }^{29}$ With 171,000 foreign nationals living in Belgium in $1890^{30}$, only slightly more than 1,500 people became Belgian nationals via naturalisation between 1881 and $1900 .{ }^{31}$ According to the 1889 Dutch census, 49 ,ooo foreign nationals were living in the Netherlands ${ }^{32}$; between 1880 and 1899 only 844 of them received the Dutch nationality via naturalisation, excluding the colonies where another 136 people received naturalisation. ${ }^{33}$

Caestecker, 'Vluchtelingen en de transformatie van het vreemdelingenbeleid in België', 359-360.

Caestecker, 'La législation belge relative à la nationalité 1830-1984', 34 .

Vanthemsche, Belgium and the Congo, 43.

Between 1894 and 1913, the Belgian parliament refused 30 percent of the applications for grande naturalisation and 10 percent of the applications for naturalisation ordinaire. Caestecker, 'La législation belge relative à la nationalité 18301984', 24.

Belgian population according to national census 1900: 6,693,548. 'RECENSEMENT- CENSUs', Statbel, https://statbel.fgov.be/fr/propos-de-statbel/quefaisons-nous/recensement-census. Accessed on 10 July 2020.

Annuaires statistiques de Belgique, Ministère de la Justice et Administrations provinciales, quoted in Nicolas Perrin and Frank Caestecker, 'Analyse démographique: les changements de nationalité, 1830-1984: aperçu statistique', in: Caestecker et al., Devenir belge, 73-102, 77-83; Caestecker, 'La législation belge relative à la nationalité 1830$1984^{\prime}, 34$. Heijs, Van vreemdeling tot Nederlander, 55. Dutch population 1900: 5,107,000, Historisch Ecologische Databank, Centraal Bureau voor de Statistiek.

Heijs, Van vreemdeling tot Nederlander, 54-101. Given the shift in legislation, one might assume that the percentage of foreign nationals who received Belgian nationality via naturalisation should be higher compared to the Netherlands, but the percentage, in actuality, is lower. Several aspects need to be born in mind when comparing the Belgian and Dutch statistics. 1. 
Naturalisation in both countries was a costly and time-consuming procedure involving both parliamentary chambers. It was considered a favour granted by the state, rather than a right. The granting of Belgian or Dutch nationality was a discretionary act of parliament, and even candidates who fulfilled all formal criteria could have their applications rejected. Vice versa, parliament could accept applications that did not comply with the formal criteria as parliamentarians did not have to account for whether an application was accepted or rejected. ${ }^{34}$ Consequently, only members of the higher social ranks, in particular those foreign-born residents who were planning a career in the public sector, including the military, and those who were well off enough to receive voting rights together with nationality, had an incentive to go through the long naturalisation procedure. ${ }^{35}$ In Belgium, about one third of those naturalised between 1880 and 1900 belonged to two professional groups: they were members of the armed forces and civil servants. ${ }^{36}$ In the Netherlands during the same period, senior members of the armed forces and tradesmen were the ones most likely to become naturalised. ${ }^{37}$ In both countries between 1880 and 1900 , almost all people who became naturalised were foreign nationals from neighbouring countries, with Germans representing the biggest share. ${ }^{38}$ Many German residents belonged to the social elite and could expect advantages from naturalisation, especially in the trading cities of Antwerp and Rotterdam. ${ }^{39}$ In the case of Antwerp, the Catholic Party even feared that if the German residents received voting rights alongside grand naturalisation, the protestant German trading community would represent a firm 'voting block' for the Liberal Party in the port city. ${ }^{40}$ Residents of German origin in some cases also opted for Belgian or Dutch nationality to avoid the heavier

The methodology used by the administrative body collecting the data might differ, for example regarding naturalisations received through marriage. 2. Legal incentives do not automatically cause a change in behavior. 3. To genuinely compare the numbers of naturalised one would need to know the number of applicants. 4. The statistic does not reflect the evolution over time, before and after reglementary change.

Caestecker, 'La législation belge relative à la nationalité 1830-1984', 13. The Dutch parliamentary records do not give any insight into the cases and the number of refused applications. Heijs, Van vreemdeling tot Nederlander, 99-100. Caestecker, 'Vluchtelingen en de transformatie van het vreemdelingenbeleid in België', 329;
Brandt, Van Leeuwen-Canneman and Van den Bergh, Naturalisatiegids, 29. Caestecker, 'La législation belge relative à la nationalité 1830-1984', 34. Heijs, Van vreemdeling tot Nederlander, 57. Perrin and Caestecker, 'Analyse démographique', 83.

Frank Caestecker and Antoon Vrints, 'The National Mobilization of German Immigrants and their Descendants in Belgium, 1870-1920', in: Panikos Panayi (ed.), Germans as Minorities during the First World War: A Global Comparative Perspective (Burlington 2014) 123-146, 124-125. DOI: https://doi.org/10.4324/9781315584645. Caestecker, 'La législation belge relative à la nationalité 1830-1984', 22. 
requirement of military service in their home country. ${ }^{41}$ Until the end of the nineteenth century, it was possible for young men to avoid military service in both Belgium and the Netherlands, particularly if they were well off. ${ }^{42}$

Among the naturalised in Belgium were also numerous people originating from the parts of Limburg and Luxembourg that the 1839 Treaty of London had integrated into the Netherlands, but which Belgium had reclaimed at its independence. Several legal measures enacted between 1879 and 1909 facilitated the naturalisation of the residents of these territories. ${ }^{43}$ In the Netherlands, after the legal reform in 1892, the so-called former-Dutch (oud-Nederlanders) who had resided abroad for ten years lost their nationality if they did not declare in writing to the authorities that they wanted to remain Dutch. Those among the oud-Nederlanders who neglected to make this declaration before 1903 contributed to the sharp increase in naturalisation numbers after the Dutch government had introduced special conditions for them to become re-naturalised. 44

\section{Candidates for Naturalisation in Antwerp}

At the end of the nineteenth century, Antwerp developed from a peripheral textile centre in the Austrian Netherlands into a major distribution port for rapidly industrialising Belgium. ${ }^{45} \mathrm{By} 1900$, the city's population totalled about 300,000 residents, making it the country's biggest city. ${ }^{46}$ As with many port cities, both Antwerp and Rotterdam owed their demographic expansion to in-migration. In 1900, about thirteen percent of Antwerp's inhabitants were non-Belgian, most often of German or Dutch origin. ${ }^{47}$ An important share of the foreign, especially German-born, residents was active in the port economy and worked within the (German) export business. ${ }^{48}$ Eastern Europeans, many of them migrants who were unable to continue their planned migration to the Americas, also contributed to the rising migrant

\section{van de grote Werkstad: een studie over de bevolking}

Peter Jan Bouman and W. H. Bouman, De Groei van Rotterdam (Assen 1952) 26.

Caestecker and Vrints, 'The National Mobilization of German Immigrants', 126.

Perrin and Caestecker, 'Analyse démographique', 78-80.

Heijs, Van vreemdeling tot Nederlander, 75.

Anne Winter, Migrants and Urban Change: Newcomers to Antwerp, 1760-1860 (London 2009).

46 Jaap Kruithof, 'De demografische ontwikkeling in de XIXe eeuw', in: Genootschap voor
Antwerpse Geschiedenis (ed.), Bouwstoffen voor de geschiedenis van Antwerpen in de XIXe eeuw: Instellingen, economie, kultuur (Antwerp 1964) 508-542, 509-510. 
population in the port cities from the 1880 on onwards. By 1900, the third-largest migrant community in Antwerp was composed of people from the Russian Empire. ${ }^{49}$ Nevertheless, the overwhelming majority of applicants for naturalisation in Antwerp originated from neighbouring countries, in particular from Germany and the Netherlands, just as it was at the national level. ${ }^{50}$

The Belgian application procedure for naturalisation started and ended at the local level. Yet, the national parliament made the final decision in a discretionary manner as to whether or not an application for naturalisation was accepted..$^{51}$ The process began with a foreign national turning in a request to the local administration. After receiving the application, the local representative of the royal prosecutor, the parquet de la ville d'Anvers, would inform national institutions about the procedure and send a note to the national prosecutor so that the responsible department at the Ministry of Justice, the Sûreté publique ${ }^{52}$, could review the application. Naturalisation essentially involved these two national institutions, the national prosecutor and the Sûreté publique, alongside the Antwerp mayor and police. As will be shown, after the national authorities had given green light it was up to the mayor and the police to evaluate the applicant and support or oppose his or her request. The large majority of naturalisation candidates were male. In the name register of foreign nationals living in the province of Antwerp who applied for naturalisation in 1895 , for example, we find only six women among the 370 candidates, while in 1896 only six out of 656 applicants were female. ${ }^{53}$ Due to this gender imbalance ${ }^{54}$, I will generally use masculine pronouns when referring to the naturalisation candidates.

Before the beginning of the legislative process that would ultimately grant naturalisation by involving both parliamentary chambers, the Sûreté publique would turn the affair over to the local authorities if the application was deemed worthy of consideration. The Surreté would ask the mayor of the Onderdanen van de tsaar, 1814-1914 (Ghent 1993) 353. responsible for border control and inspection of foreigners housed at the Belgian Ministry of Justice. The institution had its roots in the early years of Belgian independence, when it was responsible for securing the young state's borders. Regulated by royal decree, the Sûreté publique evolved into a flexible body with rather unclear areas of responsibility, including the observation, control, and expulsion of nonnationals. 
city to set up a report about the applicant's 'behaviour, morality, criminal record, and solvency'. ${ }^{55}$ The mayor would then pass the case further down the administrative scale to the police force for the city section where the foreign national was registered. A police agent would have to inform the mayor as to whether the candidate had a record of outstanding morality and behaviour, and whether there were any recorded judicial incidents. He would also need to confirm the candidate's financial solvency by investigating his profession and income. If the Antwerp mayor transferred a positive report of the candidate to the royal prosecutor, he had officially confirmed his support for the foreign resident's application for naturalisation by acting as his guarantor. After the legislative procedure had been carried out on the national level, the foreign national would present himself to the mayor and declare that he accepted the naturalisation and would pay the necessary fees. If the applicant failed to do so within three months, his Belgian nationality would be withdrawn.

In the case of the German national Carolus-Frederik-Eduardus Karcher, who applied for grand naturalisation in 1887 , the police commissar confirmed that the candidate resided in Antwerp, and had lived there for sixteen years with only one year of interruption. ${ }^{56}$ Continuous residency was crucial when applying for naturalisation in Antwerp, as well as in Rotterdam. A formal proof of residency would not have sufficed; rather it was the candidate's actual local presence and reputation that mattered. Paradoxically, foreign nationals had to prove their local rootedness and belonging when applying for naturalisation. Yet, in the case of the port cities, where an increasing number of foreign tradespeople set up their business in the late nineteenth century, long-time local presence in the ports was supposedly attributable to economic activities and not proof of meaningful allegiance to their country of residence. Hence, the city's interests - and especially the economic advantages a city could expect from the continued presence of the foreign national - played a key role in the naturalisation procedures at the local level. References to national allegiance and belonging are hardly discernible in the local administrative procedures.

Besides irreproachable moral behaviour, the police commissar had to testify to the applicant's marital status, which was generally recorded in the local register books kept at the police station. ${ }^{57}$ The 1881 Belgian naturalisation law required people applying for grand naturalisation to be married or, if their spouse was deceased, to have children from that marriage. Unmarried individuals or those without children from a previous marriage could only become naturalised at the age of fifty. Along with permanent publique to the Antwerp mayor

(20 December 1887) in the case of CarolusFrederik-Eduardus Karcher's application for grand naturalisation in 1887 , in: CAA, ABS, Naturalisaties 731/1987.
56 Letter from an Antwerp police commissar to the Antwerp mayor, 31 December 1887, in: Dossier Carolus-Frederik-Eduardus Karcher, CAA, ABS, Naturalisaties 731/1987.

57 See the records in CAA, Veiligheid, Politie, Decentrale werking. 
residency, marriage was considered a stabilising factor binding the foreign national to the local community. Although being married to a Belgian woman was advantageous for the candidate ${ }^{58}$, it was still better to be married to a non-Belgian woman than to not be married at all. ${ }^{59}$ The local authorities took marriage as an indication that the foreign national was settled in Antwerp. Thus, a marriage certificate was generally enclosed with the application for ordinary or grand naturalisation. At the same time, the naturalisation law from 1881 also stipulated that marriage was not required if the candidate's father had already received grand naturalisation in Belgium. Accordingly, the German applicant Carolus-Frederik-Eduardus Karcher, a single man working as a commission agent at his father's harbour business in Antwerp, could apply for grand naturalisation because his father was a naturalised Belgian. Hence, local belonging could likewise be proven with family ties that linked the foreign national to a particular place, rather than to the nation as an 'imagined community'. ${ }^{\circ}$

Throughout the local naturalisation procedure, the candidate was in constant contact with the local administrations, sending letters back and forth and turning in various documents, such as a marriage certificate or proof of fulfilled military service. When transferring the completed dossier to the royal prosecutor, the mayor acted as an advocate for the foreign national living in Antwerp. ${ }^{61}$ He presented his case in a favourable light and closed his letter with the standard formulation: 'J'estime que cette demande peut être favorablement accueillie' ('I think that this application deserves favourable consideration' ${ }^{62}$; or '[s] a demande mérite tout appui' ('this request deserves all-out support'). ${ }^{63}$ The different local authorities who contributed to the naturalisation process - the mayor, the police, and the parquet - spoke and acted on the candidate's behalf so that his request for naturalisation would be successful at the national level. Rather than establishing a closer bond between the foreign national and the nation state, the naturalisation procedure was a local endeavour to further integrate an often economically successful city dweller into the local community.

Reflections on the Origin and Spread of Nationalism (London/New York 2006).

61 In the city archives, we only find dossiers by those candidates whose application the mayor forwarded to the national authorities. As to those applications that the mayor considered insufficient, we may assume that they were not transmitted to the national level. See for example letter from the Antwerp mayor to the royal prosecutor, 17 January 1888 , in: Dossier Carolus-Frederik-Eduardus Karcher, CAA, ABS, Naturalisaties 731/1987.

63 See for example letter from the Antwerp mayor to the royal prosecutor, 24 December 1877, in: Dossier Alfred Schuchard, CAA, ABS, Naturalisaties $713 / 1981$. 
The local naturalisation practice was also framed by the national legal context. Indeed, local practice in Antwerp shifted after the introduction of the 1881 naturalisation law. The sheer volume of archival records demonstrates that the liberalisation of grand naturalisation provoked an increase in applications. ${ }^{64}$ As will be shown, with the 1881 legal reform, local authorities became more inclined to support applications for naturalisation by wealthy individuals even if applicants did not fulfil all formal criteria. This development differed from previous practices as exemplified by the case of Charles Langsdorf. In 1870, the German businessman Charles Langsdorf, who had settled in Antwerp as early as 1845 and ran a successful business in the port, had to testify to his irreproachable behaviour prior to his arrival in Belgium when applying for naturalisation. The Belgian Senate asked Langsdorf to prove that he had 'honourably left' the different countries where he had lived before arriving in Belgium. ${ }^{65}$ In a personal letter addressed to the Antwerp police commissar, Langsdorf did not hide his indignation about these exorbitant administrative demands - about 'l'inconvenance d'une telle demande' ('the impropriety of this request') - renouncing his former wish to become Belgian. ${ }^{66}$ Such incidents of successful but highly mobile businessmen of good repute being denied naturalisation or refusing it because of administrative requirements became much less common after the naturalisation law from 1881.

One applicant, Alfred Schuchard, a German citizen who was born in Prussia, conducted trade in Antwerp and held the position of vice-consul of Uruguay. He is a telling example of the multiple, synchronous belongings that characterised many port city dwellers. ${ }^{67}$ The transnational life path of the aforementioned Carolus Karcher too indicates that the 1881 legislation encouraged mobile people to apply for Belgian nationality and citizenship. Upon Karcher's arrival in Antwerp, the German national, born in Saarbrücken in Prussia, proved his identity with a certificate issued by the consul of the United States of America in The Hague. Karcher's national belonging was unclear to the point that the Ministry of Justice wrongly referred to Karcher as a French national in its communications with the city administration. In 1887 , he applied for grand naturalisation, available to him thanks to his father's naturalisation. Karcher's application for grand naturalisation, which also ensured his political rights, was supported by the Antwerp mayor. He owed this to being part of a successful and locally rooted family business.

64 CAA, ABS, Naturalisaties 731/1981.

65 Letter from the Provincial government to the Antwerp administration, 24 February 1870, in: Dossier Charles Langsdorf, CAA, ABS, Naturalisaties 713/1979.
66 Letter from Charles Langsdorf to an Antwerp police commissar, 9 March 1870, in: Dossier Charles Langsdorf, CAA, ABS, Naturalisaties 713/1979.

67 Dossier Alfred Schuchard; CAA, ABS, Naturalisaties $713 / 1981$ 
Moreover, his father's status as a naturalised Belgian meant that Karcher had no obligation to have served in the Belgian or German military.

The military service requirement was problematic for many applicants with confusing transnational trajectories. However, not having served in the army was not an insurmountable obstacle for an application to receive support from the Antwerp authorities: if the foreign national was a 'desirable person', the city authorities might support his application anyway. Sigismond Weiler, born in Prussia in 1857, was denaturalised of his German nationality at seven years of age and arrived in Antwerp at the age of eighteen without a nationality. As he had not completed any military service at that point, he would have been required to register for the drawing of lots by which military recruits were chosen in Belgium every year. ${ }^{68}$ Weiler failed to do this, as the Antwerp mayor reported to the royal prosecutor in May 1882. ${ }^{69}$ His naturalisation procedure was suspended, but six years later, Weiler re-applied for naturalisation though he had still not fulfilled all legal requirements, having neither served in the military, nor been married. The Antwerp mayor decided to support Weiler's application nonetheless. He professed in a letter to the royal prosecutor that Weiler's 'behaviour and morality have remained irreproachable and his commercial reputation is good'. ${ }^{70}$ In fact, he had turned into a successful businessperson and thereby into a desirable Antwerp citizen, as the police commissar's report confirmed. The candidate's seed and flour business had done very well and his revenues were high. ${ }^{71}$ The Antwerp city administration too supported the application of David-Emiel Spudich, the owner of a popular eatery in Antwerp, whose history was even more complicated. Since Spudich had no genuine place of origin, he had not completed any military service. Born in 1856 in a village close to Alt Christburg in West Prussia ${ }^{72}$, Spudich's father emigrated to Russia in 1859 and was eliminated from the Prussian registers. Spudich himself travelled around Prussia and lived in Poznań, moved to Rotterdam and then to Amsterdam, where he lived without official registration, before settling in Antwerp.

The cases of these candidates suggest that the Antwerp authorities were eager to accommodate the particularities of the port city's mobile inhabitants and the legal requirements for naturalisation. Local authorities showed a strong interest in supporting the rather problematic applications from these individuals with transnational trajectories, no fixed residency, and whose

Sigismond Weiler, CAA, ABS, Naturalisaties $731 / 1987$. the Antwerp mayor, 15 March 1888, in: Dossier Sigismond Weiler, CAA, ABS, Naturalisaties $731 / 1987$. 


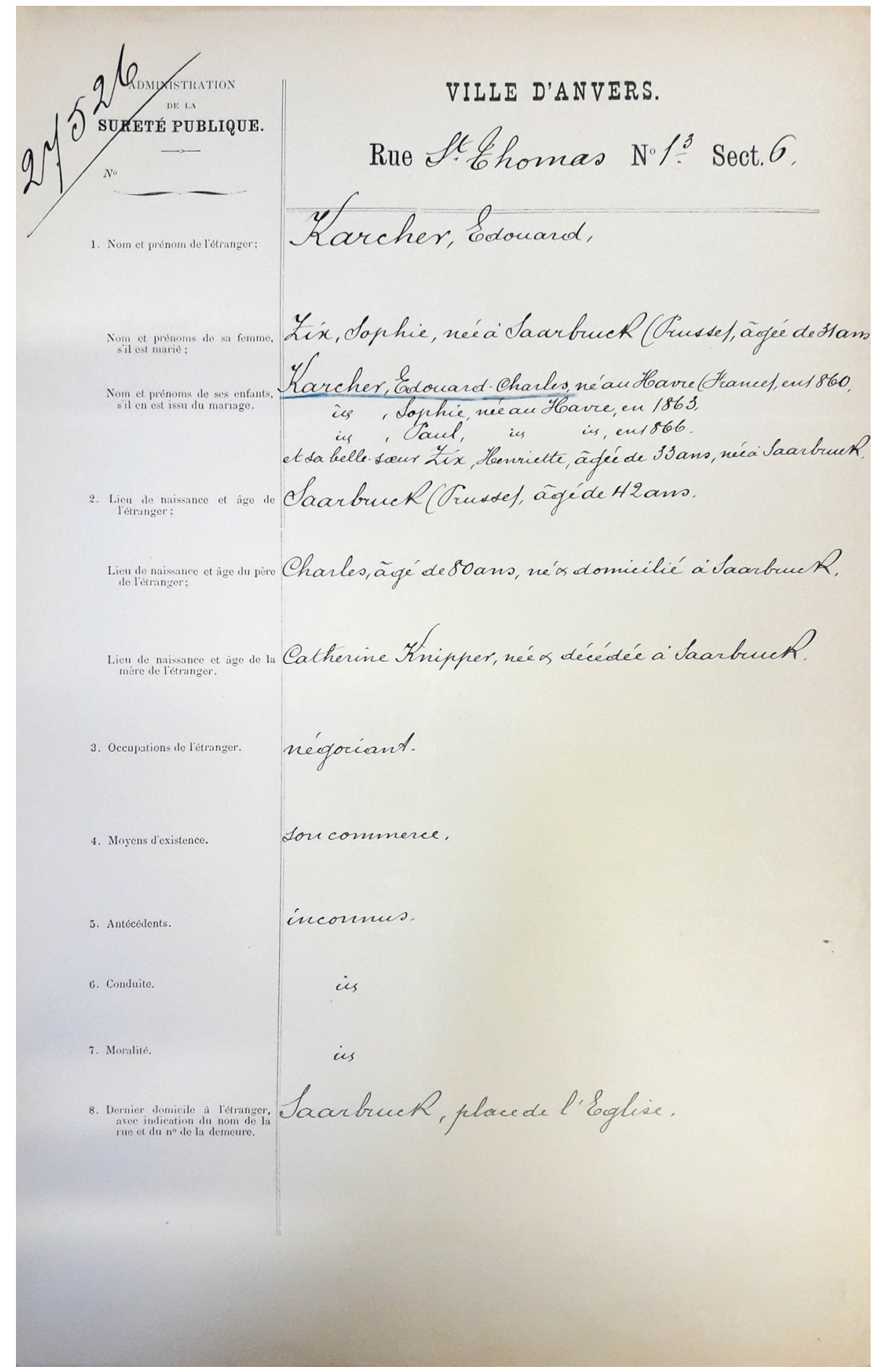

Upon their arrival in Belgium, foreign nationals had to register with the national Sûreté publique by filling in a so-called foreigner file. These registration certificates were a central piece in the application dossiers for naturalisation, like in the case of Edouard Karcher. The document is held by the Antwerp City Archives. FelixArchief, Antwerp city archives, 713\#1981, nr. 222, copy from foreigner file 481\#27526. 
connection to Belgium as a nation was minimal, but who were operating successful businesses in the port city. The local authorities certainly felt legitimised to reinforce these applications thanks to a legal context that, since 1881, made Belgian nationality more accessible for foreign-born residents. In Rotterdam, on the contrary, the authorities dealing with applications for naturalisation on the local level had to take into account the more restrictive regulations of the 1892 nationality law that entered into force on 1 July 1893 .

\section{Applying for Dutch Nationality or Denizen Status in Rotterdam}

In the last quarter of the nineteenth century, Rotterdam expanded demographically and transformed economically into an international port. Around 1850 the city had about 90,00o inhabitants, but this number grew to approximately 320,000 by 1899 . Rotterdam began to attract migrants during the 1870 s port expansion, many of whom arrived from the national hinterland. Between 1880 and 1900, only a small share of migrants came from abroad, primarily from Germany and Belgium, with the community of German-born residents representing approximately two percent (circa 4,010 people) of Rotterdam's population in $1889 . .^{73}$ The German-born residents, whose move to Rotterdam was often prompted by commercial and trade interests, had, on average, a higher social status than Rotterdam-born inhabitants. ${ }^{74}$ Towards the end of the nineteenth century, the community of Eastern Europeans had grown in Rotterdam just as it had in Antwerp. Russian migrants especially became more numerous, but their overall number remained small, with only 229 registered Russian nationals living in Rotterdam between 1893 and $1914 \cdot{ }^{75}$ As in Antwerp, applications for naturalisation came almost exclusively from people from neighbouring countries, with Germany representing the majority. ${ }^{76}$

Before 1893, when the nationality law abolished the denizen status, in contrast to Antwerp where this procedure seemingly became obsolete after 1881 , foreign-born residents in Rotterdam were more likely to apply there life outside the migrant network? German immigrants in XIXth century Netherlands and the need for a more balanced migration typology',

Annales de démographie historique 104:2 (2002) 2950, 34. DOI: https://doi.org/10.3917/adh.104.0029. vertrokken": Immigranten toen en nu (18702005)', in: Paul van de Laar, Leo Lucassen and Kees Mandemakers (eds.), Naar Rotterdam: Immigratie en levensloop in Rotterdam vanaf het einde van de negentiende eeuw (Amsterdam 2006) 25-38.

Peter Tammes, 'Vestiging van joden uit Rusland in Rotterdam', in: Peter Tammes (ed.), Oostjoodse Passanten en Blijvers: Aankomst, opvang, transmigratie en vestiging van joden uit Rusland in Amsterdam en Rotterdam, 1882-1914. Menasseh ben Israel Instituut Studies IX (Amsterdam 2013) 73-93, 75. City Archives Rotterdam (hereafter CAR), Archief Gemeentesecretarie (hereafter AG), 494-01/151 Register genaturaliseerde personen 1839-1900. 
for civil equality with Dutch nationals than for naturalisation. The mayor and municipal council carried out 106 equalisation procedures between 1866 and $1892 .{ }^{77}$ Among these 106 applicants, mostly from the German Confederation and later the German Empire, there was only one woman, supposedly unmarried. In contrast to the application for Dutch nationality, the equalisation procedure was straightforward: the candidate was only asked to prove that he had resided in the municipality for at least six years. Such evidence could easily be produced if the foreign national had, in compliance with legal requirements, registered with the Rotterdam authorities upon arrival in the city. ${ }^{78}$

The certificates verifying a foreigner's legal equality with Dutch nationals were collected by the Gemeentesecretarie van Rotterdam, afdeling bevolking (municipal government Rotterdam, population department) in a huge volume of forms. The forms, filled out by the civil agents, recorded the foreign national's name and his town and country of birth, and attested to the applicant's uninterrupted residency in Rotterdam, a requirement to attaining legal equality with Dutch nationals according to Article Eight of the Civil Code. This reference to the Burgerlijk Wetboek was the only reference made to the nation state on the form. On the form, the city and its representatives were clearly presented as the central actors conferring legal equality, with the form's title stating that 'Burgemeester en wethouders van Rotterdam verklaren bij deze dat [...]' ('the mayor and aldermen hereby declare that [...]'). The same holds true for the certificate granted to the successful applicant: it contained the stamp of the city of Rotterdam as the only official signature and made no mention of the Dutch nation state. Local authorities were decisive actors and residency was the only criterion for becoming legally equal to Dutch nationals, though it should be stressed that this precondition was taken very seriously. Johann Hermann Joseph Lindemann from Hannover in Prussia, for example, saw the equal rights he acquired in 1869 withdrawn after the Rotterdam police commissar discovered that his statement of an uninterrupted six years of residency was false. ${ }^{79}$

The abolition of this rather easy way to gain Dutch civil rights in 1893 did not provoke a rise in naturalisation numbers, because the new nationality law also made the naturalisation procedure more costly. Between 1839 and 1900, only 126 people were naturalised in Rotterdam. In 1890 , for example, six residents were naturalised, some of whom had a professional incentive to become Dutch: Michael Feilzer, a cook born in Prussia; David Croll, an engineer born in Scotland; Matthias Högel, a photographer born in verklaringen van zesjarige inwoning 1839-1892. and Antwerp, see: Reimann, 'People on Lists in Port Cities'.
CAR, AG, 494-01/391 Registers van afgegeven verklaringen van zesjarige inwoning 1866-1892, Dossier Lindemann. 
Prussia; Egenius Coremans, a customs officer at the Dutch railway company born in Belgium; Ernst Luhde, a sergeant in the armed forces in the DutchIndies born in Mecklenburg-Schwerin and Louis Müldner, a machinist at the Dutch railway company born in Prussia. In 1892, only two foreign-born Rotterdam residents received naturalisation: Peter Bruckschen, a civil servant born in Prussia and Gustav Schenk, a merchant born in Hamburg. In 1894, four people from Germany and one from Russia were naturalised and none received naturalisation in $1896 .^{80}$ The city's election registers of the $1890 \mathrm{~s}$ only list a total of seventy-seven naturalised electors. ${ }^{81}$

Similar to Belgium, naturalisation in the Netherlands was a parliamentary decision: it was conferred by law, approved by both parliamentary chambers, and executed by the Ministry of Justice. The municipal authorities received a copy of the law, which was also introduced into the Staatsblad van het Koninkrijk der Nederlanden (Official Gazette of the Kingdom of the Netherlands). Once the law was approved, the foreign national had to declare to the municipal authorities that he - between 1839 and 1900 not a single women figured among the naturalised in Rotterdam accepted his naturalisation. By noting this declaration in the register book, the Rotterdam civil agent completed the naturalisation procedure. Nevertheless, even before this final act, naturalisation was a municipal concern. As in the case of legal equality, the applicant had to provide a certificate demonstrating that he was registered as a resident of the city. But, this formal proof of local residence did not suffice; in addition, the candidate's neighbours or acquaintances had to confirm by written statement that the applicant had a continuous presence in the neighbourhood and that they were personally familiar with him. ${ }^{82}$ The local residents acted as guarantors by signing a formal declaration stating that 'op hunne persoonlijke verantwoordelijkheid' ('on their own responsibility') they affirmed being 'zeer goed bekend' ('very well acquainted') with the candidate. Only a few dossiers contain, apart from this declaration of oath, a note from the Rotterdam police commissar confirming these declarations and commenting on the applicant's good behaviour. In the case of Carl Clemens August Schade's application for naturalisation in 1893 , the commissar noted that the guarantors claimed to know Schade very well, having conducted business with him. ${ }^{83}$

It is certainly no coincidence that the police were involved with naturalisation applications made by two Eastern Europeans in 1892. In the context of mass migration through Western European port cities where a great number of emigrants were stranded for long periods of time, people from relatively poor regions in Eastern Europe increasingly raised suspicion personen 1839-1900.
82 Individual naturalisation dossiers are stored in CAR, AG, 494-01/152 Naturalisaties 1875-1893.

83 Dossier Carl Clemens August Schade, in: CAR, AG, 494-01/152 Naturalisaties 1875-1893. 
No. 17 t.

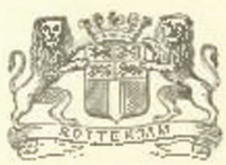

Bew ijs van Inschrijving.

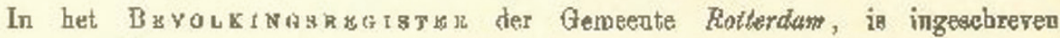

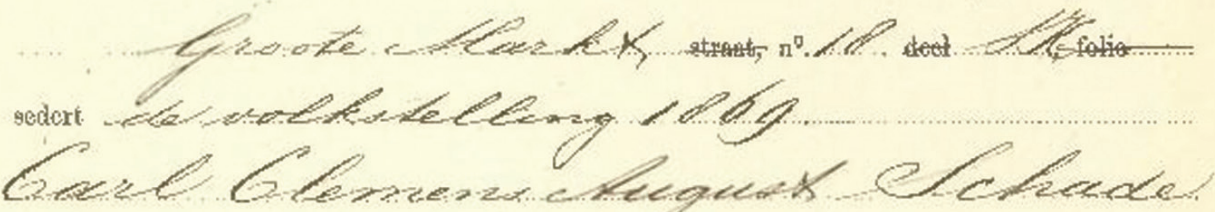

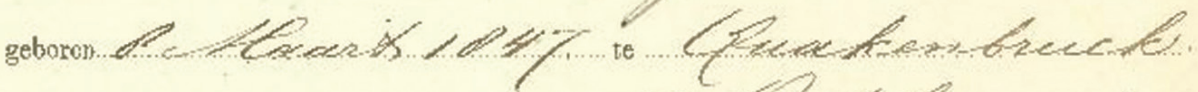

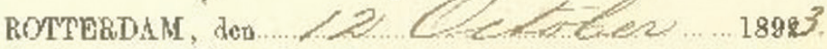

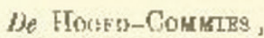
Nrimens heri,

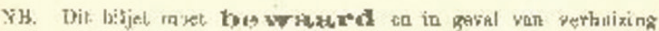
medigabinkit on vertoona wordisu.

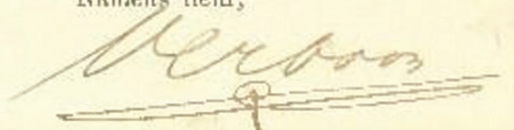

A certificate of registration in the population register of Carl Clemens August Schade, produced by the municipality of Rotterdam on 12 October 1893 . These certificates were added to applications for naturalisation. The document is held at the Rotterdam City Archives. Stadsarchief Rotterdam, Archief Gemeentesecretarie, 494-01/152. 
among authorities fearing these people would become a burden to the municipal poor relief. ${ }^{84}$ In the case of Frantz Julius Benjamin Voelcken, born in Danzig in West Prussia ${ }^{85}$, the police commissar confirmed his marriage, commented on his Rotterdam addresses, and noted his professional position and moral behaviour. ${ }^{86}$ In the case of August Johann Gustav Hernmarck, born in Riga in Russia, the police commissar simply confirmed that his acquaintances had testified to his continuous presence in the city. ${ }^{87}$ As in Antwerp, the local rootedness of a foreign national, as assessed by local authorities, was an important precondition for the success of a naturalisation request.

Dissimilar to Belgium, where categories of good behaviour and morality were a part of the application forms for naturalisation, the Dutch 1850 Nationaliteitswet (nationality law) dropped the formal requirements concerning moral behaviour and sufficient means of subsistence. In practice, however, these criteria were still relevant, as attested by dossier notes from the Rotterdam police. ${ }^{88}$ A new national's 'bad behaviour' or insufficient financial means would have first and foremost affected the local rather than the national community, so the Rotterdam authorities continued to check the applicants' moral and economic behaviour. But, the control that Rotterdam's local authorities had over naturalisation procedures did not extend to reinforcing the naturalisation of 'desirable' immigrants. Unlike in Antwerp, where authorities supported or even pushed for the naturalisation of foreign nationals who could contribute to the local economy, we do not find evidence of such endeavours in the Rotterdam archives.

Compared to the Belgian procedure, the number of formal requirements to be met locally was low in the Netherlands, as morality and sufficient financial means were stricken from the formal criteria. In comparison to Antwerp, the individual naturalisation dossiers held at the Rotterdam archives are much thinner: the latter contain a certificate of registration, a declaration of oath signed by the local resident, and in some cases a note from the police commissar, most often regarding the applicant's morality. The Antwerp authorities manipulated different formalities by ignoring, overlooking, or insisting on one requirement over another. With numerous formal requirements to be met at the local level, Antwerp authorities adapted their assessment of these criteria to suit the port city's interest in integrating a foreign national. If the person was married, possessed in Times of Cholera: Eastern European Migrants in Rotterdam and Antwerp (c. 1880-1914)', in: Sari Nauman et al. (eds.), Baltic Hospitality from the Middle Ages to the Twentieth Century - Receiving Strangers in Northeastern Europe (Palgrave Macmillan, forthcoming 2022).
85 Today's Gdańsk in Poland.

86 Dossier Frantz Julius Benjamin Voelcken, in: CAR, AG, 494-01/152 Naturalisaties 1875-1893.

87 Dossier August Johann Gustav Hernmarck, in: CAR, AG, 494-01/152 Naturalisaties 1875-1893.

88 See also Heijs, Van vreemdeling tot Nederlander, 38. 
sufficient financial means, or if he had fulfilled military service, these formal criteria were assessed, with special consideration for economic merits. The Antwerp authorities did so in a legal context designed to facilitate the integration of foreign-born residents into the legal nation. The opposite was true in the Netherlands, where the nationality law of 1892 made naturalisation even less accessible. Costs related to naturalisation rose and, most importantly, naturalised people were forced to relinquish their original nationality. While some states like Russia generally refused denationalisation requests, others, like Belgium, had special regulations regarding the denationalisation of young men bound to do military service. ${ }^{89}$ In a legal context where foreign nationals were deterred from requesting formal integration into the Dutch legal nation, Rotterdam authorities, unlike their Antwerp counterparts, did not endeavour to foster the naturalisation of the city's foreign-born residents.

\section{Conclusion}

In the late nineteenth century, both Dutch and Belgian nationalisation legislation attempted to define the connection that foreign-born nationals had to their new home countries. However, the application for naturalisation both originated from, and was concluded in, the local context. After examining the local practice of naturalisation procedures in both Antwerp and Rotterdam, we can assume that local belonging played a role in whether an application for naturalisation was successful. In Rotterdam, applicants had to prove their local rootedness by mobilising their neighbours to speak on their behalf. In Antwerp, if candidates were not able to convince the mayor and police commissar to issue the necessary certificates and to speak in their favour, they would have little chance of becoming naturalised, given that parliament generally rejected a large number of applications.

In both port cities, local authorities checked and reported on the applicants' morality and behaviour. In Antwerp, this control was not primarily a local initiative. The Belgian law required the local authorities to conduct these checks and applications could be rejected by parliament if candidates were considered to be political opponents. ${ }^{90}$ According to the Dutch law of 1850 , local authorities were no longer required to investigate and report on the applicants' morality. The Dutch state further refrained from openly expelling foreign anarchists because such action would have harmed the state's liberal image.${ }^{91}$ We might deduce that the Rotterdam authorities did not feel comfortable with the nation state's liberal attitude 
and, hence, took their own initiative to ensure that those applying for naturalisation in their locality were morally irreproachable and would not disrupt the social order.

On the other hand, the local authorities in Rotterdam intervened less on behalf of their local candidates for naturalisation than their Antwerp counterparts did, as shown by the comparatively thin application files stored in the Rotterdam archives. One reason for this difference might be that the legal context in which the Dutch local authorities were acting provided no incentive for foreign nationals to apply for naturalisation. Compared to the authorities in Antwerp, the Rotterdam authorities seemed to feel less empowered to speak in favour of their local candidates. While acting in their cities' interests - either by further integrating an economically successful resident or by making sure that the new national would not disrupt the social order - the local authorities were operating within a national legal context. We therefore need to acknowledge that the port cities' authority was shaped by national legislation with practices reflecting state-determined politics surrounding nationality and citizenship.

National ideology did not drive administrative procedures in the port cities. Yet, due to the importance of social standing and esteem, which, considering the competition between Europe's leading ports, were generally linked to the candidate's economic performance, most people who received Belgian or Dutch nationality via naturalisation, were Western Europeans. The members of the migrant communities from neighbouring countries, German communities in particular, were most successful economically, while they were, at the same time, particularly mobile and in many cases not especially attached to their country of residence. The Antwerp authorities endeavoured to accommodate these applicants' transnational life paths with the legal requirements, which expected the naturalised citizen to be loyal to the Belgian state rather than to any specific city.

In both cities, the local naturalisation practice favoured the naturalisation of Western Europeans by insisting on personal contacts between the applicant and their local acquaintances. This procedure benefitted those who were similar to the local population more than those who were different, thereby curbing the development of a diverse legal community. Moreover, the local naturalisation procedure in Antwerp and Rotterdam did not mirror the gender diversity of the port cities' migrant population: apart from very few exceptions, applicants for naturalisation were male, a reflection of women's marginal position within the legal nation. The cities' actual openness to mobile people, which increased during the age of steam (c. 1870-1940), did not mean that all newcomers were equally welcomed into formal membership in the city or national community. The vast majority of foreigners who lived in the port cities did so without requesting naturalisation. 
Christina Reimann is a historian specialised in modern European transnational history. Her research deals with cultural legal history, the history of migration, port cities, and urban pleasure culture. Since 2019, she is a post-doc researcher at the Universities of Stockholm and Södertörn (Stockholm) and affiliated to two collective research projects, the HERA-funded project 'Pleasurescapes. Port cities' transnational forces of integration' and the project 'Baltic Hospitality. Receiving and rejecting strangers on the Baltic rim (1000-1900)' funded by the Swedish Foundation for Baltic and East European Studies. Recent key publications are Christina Reimann and Martin Öhman (eds.), Migrants and the Making of the Urban-Maritime World: Agency and Mobility in Port Cities, c. 15701940. Routledge Advances in Urban History (New York 2020), and 'People on Lists in Port Cities: Administrative Migration Control in Antwerp and Rotterdam (c. 1880-1914)', Journal of Migration History 6:2 (2020) 182-208. DOI: https://doi.org/10.1163/2351992400602002. E-mail: christina.reimann@sh.se. 